\title{
Pengaruh Pemberian Ekstrak Biji Pepaya (Carica papaya L.) terhadap Kualitas Sperma
}

\author{
Muhammad I. Syamsuddin, ${ }^{1}$ Grace L. A. Turalaki, ${ }^{2}$ Lydia E. N. Tendean ${ }^{2}$
}

\author{
${ }^{1}$ Program Studi Pendidikan Dokter Fakultas Kedokteran Universitas Sam Ratulangi \\ Manado, Indonesia \\ ${ }^{2}$ Bagian Biologi Fakultas Kedokteran Universitas Sam Ratulangi Manado, Indonesia \\ Email: muh.irfan913@gmail.com
}

\begin{abstract}
Spermatozoa is a form of mature cells from cells germinal contained in the seminiferous tubules. The quality of spermatozoa can be seen from several parameters such as concentration, motility and morphology of spermatozoa. One of the plants that have the ability to affect the quality of spermatozoa is the seeds of the pepaya plant (Carica papaya L.). The purpose of this study was to determine the effect seed extract of papaya (Carica papaya L.) on the quality of spermatozoa, especially the concentration, motility and morphology of spermatozoa. This research is a literature review conducted by identifying and interpreting all the results of certain studies. Literature was obtained from the databases Pubmed, Sciencedirect, and Google Scholar. Based on the inclusion and exclusion criteria, 14 literatures were obtained. All selected literature are experimental form research. This study shows that 14 selected literatures, 8 literatures which the research result data gives a significant response in the form of a decrease in spermatozoa concentration, 13 literatures which the research result data gives a significant response in the form of decreased spermatozoa motility and 12 literatures which the research result data gives a significant response in the form of decreased normal morphology of spermatozoa. Conclusion: Seed extract of pepaya (Carica papaya L.) affects the quality of spermatozoa by reducing the concentration, motility and morphology of spermatozoa.
\end{abstract}

\begin{abstract}
Abstrak: Spermatozoa merupakan bentuk sel matur dari sel germinal yang terdapat dalam tubulus seminiferus. Kualitas spermatozoa dapat dilihat dari beberapa parameter seperti konsentrasi, motilitas dan morfologi spermatozoa. Salah satu tanaman yang mempunyai kemampuan untuk memengaruhi kualitas spermatozoa adalah biji tanaman pepaya (Carica papaya $L$.). Tujuan penelitian ini adalah untuk mengetahui pengaruh pemberian ekstrak biji pepaya (Carica papaya $L$.) terhadap kualitas spermatozoa terutama konsentrasi, motilitas dan morfologi spermatozoa. Penelitian ini merupakan penelitian yang bersifat studi pustaka (literature review) yang dilakukan dengan cara identifikasi dan interpretasi terhadap semua hasil penelitian tertentu. Literatur diperoleh dari database Pubmed, Sciencedirect, dan Google Scholar. Berdasarkan kriteria inklusi dan eksklusi didapatkan 14 literatur. Semua literatur yang terpilih adalah penelitian bentuk eksperimental. Penelitian ini menunjukkan bahwa dari 14 literatur yang terpilih, 8 literatur yang data hasil penelitiannya memberikan respon bermakna berupa penurunan konsentrasi spermatozoa, 13 literatur yang data hasil penelitiannya memberikan respon bermakna berupa penurunan motilitas spermatozoa dan 12 literatur yang data hasil penelitiannya memberikan respon bermakna berupa penurunan morfologi normal spermatozoa. Simpulan: Ekstrak biji pepaya (Carica papaya L.) memengaruhi kualitas spermatozoa yaitu menurunkan konsentrasi, motilitas dan morfologi spermatozoa.
\end{abstract}

Kata kunci : Ekstrak biji pepaya, kualitas spermatozoa, konsentrasi spermatozoa, motilitas spermatozoa, morfologi spermatozoa 


\section{PENDAHULUAN}

Spermatozoa merupakan bentuk sel matur dari sel germinal yang terdapat dalam tubulus seminiferus. Spermatozoa ini merupakan sel memanjang, terdiri dari kepala yang mengandung inti dan ekor yang mengandung perangkat yang diperlukan untuk motilitasnya. Sel sperma pertama kali dilihat oleh Johan Ham yang mengatakan kepada Antoni van Leeuwenhoek bahwa dia telah melihat "zaaddiertjes/ animalcules/ hewan kecil" dalam cairan mani manusia tahun $1677 .{ }^{1}$ Spermatozoa merupakan hasil dari rangkaian proses spermatogenesis yang berlangsung selama 74 hari. ${ }^{2,3}$

Kualitas spermatozoa dapat dilihat dari beberapa parameter seperti konsentrasi, motilitas dan morfologi spermatozoa. ${ }^{4}$ Nilai acuan untuk konsentrasi sperma biasanya dinyatakan lebih besar dari 20 hingga 250 juta sperma per mililiter dengan batas konsentrasi antara 10 dan 20 juta per mililiter. Sperma yang mampu bergerak maju dan progresif sangat penting untuk kesuburan. Karena begitu masuk ke serviks, sperma harus mendorong dirinya sendiri melalui mukosa serviks menuju uterus, tuba falopi, dan ovum. Adanya sperma yang secara morfologis abnormal dapat menyebabkan infertilitas. Morfologi sperma dievaluasi dengan memperhatikan struktur kepala, leher, bagian tengah, dan ekor. Kelainan morfologi pada bagian kepala berhubungan dengan penetrasi ovum yang buruk, sedangkan kelainan pada bagian leher, bagian tengah, dan ekor memengaruhi motilitas spermatozoa. ${ }^{5}$ Salah satu tanaman yang mempunyai kemampuan untuk memengaruhi kualitas spermatozoa adalah biji tanaman pepaya (Carica papaya L.). ${ }^{6}$

Pepaya (Carica papaya L) merupakan salah satu anggota tumbuhan berbunga yang termasuk dalam famili Caricaceae. Pada penelitian yang dilakukan oleh Sri Nita (2019) yang meneliti mekanisme antifertilitas fraksi biji pepaya (Carica papaya L.) pada tikus jantan (Rattus norvegicus L.) galur Sprague Dawley. Pada penelitian ini, didapatkan adanya penurunan jumlah spermatosit primer dan spermatid setelah pemberian fraksi biji sebanyak $100 \mathrm{mg} / \mathrm{kb}$ BB pepaya selama 24 hari. Dari hasil penelitian didapatkan adanya senyawa n-Heksan yaitu steroid, terpenoid, saponin dan flavonoid. Fraksi etil asetat didapatkan senyawa steroid, terpenoid dan flavonoid. Fraksi etanol air didapatkan senyawa terpenoid dan flavonoid. Pada pemberian fraksi nHeksana biji pepaya didapatkan penurunan berat dari vesikula seminalis dan prostat walaupun tidak signifikan sedangkan pada pemberian fraksi etil asetat terjadi peningkatan yang signifikan dibandingkan kontrol dan n-Heksana. Hal ini mungkin disebabkan oleh kandungan senyawa yang ditemukan pada fraksi n-Heksana yaitu steroid, terpenoid, saponin dan flavonoid. Bentuk senyawa saponin ini dapat berupa steroid dan triterpenoid glikosida. Efek biologis yang ditimbulkan oleh saponin dapat mengganggu permeabilitas membran, imunostimulan, antikarsinogenik dan antifertilitas. Saponin memiliki kemampuan untuk berikatan dengan reseptor steroid kompleks yang menyebabkan reseptor androgen tidak terbentuk. Hal ini menyebabkan testosteron tidak dapat berfungsi sebagaimana mestinya. ${ }^{7}$

Penelitian ini bertujuan untuk mengetahui pengaruh pemberian ekstrak biji pepaya (Carica papaya L.) terhadap kualitas spermatozoa terutama konsentrasi, motilitas dan morfologi spermatozoa.

\section{METODE PENELITIAN}

Penelitian ini merupakan penelitian yang bersifat studi pustaka (literature review) yang dilakukan dengan cara identifikasi dan interpretasi terhadap semua hasil penelitian tertentu. Penelitian dilakukan pada bulan September-Desember 2020. Data dikumpulkan dengan cara mengakses secara daring dari 3 database Pubmed, Sciencedirect, dan Google Scholar. Hanya literatur yang berisi teks lengkap yang dimasukkan dalam penelitian ini. Pencarian dilakukan dengan memasukkan kata kunci Biji Pepaya 
(Carica papaya L), Sperma dan Antifertilitas, baik dalam Bahasa Indonesia maupun Bahasa Inggris. Batasan tahun dalam pencarian literatur untuk penelitian ini adalah literatur terbitan 10 tahun terakhir. Kriteria inklusi dalam penelitian ini adalah literatur yang meneliti tentang efek ekstrak biji papaya (Carica papaya $L$.) terhadap kualitas spermatozoa dengan parameter yang dinilai konsentrasi, motilitas maupun morfologi spermatozoa; Jenis penelitian eksperimental. Kriteria eksklusi dalam penelitian ini adalah literatur yang tidak meneliti tentang efek ekstrak biji papaya (Carica papaya L.) terhadap kualitas spermatozoa dan tidak menyertakan parameter konsentrasi, motilitas maupun morfologi spermatozoa; dokumen skripsi; Bukan jenis penelitian eksperimental. Literatur yang didapatkan dari tiga database yang digunakan berjumlah 5 dari Pubmed, 121 dari Sciencedirect, dan 4.419 dari Google Scholar $(\mathrm{n}=4.545)$ sesuai dengan kata kunci yang telah ditentukan. Hasil pencarian disaring berdasarkan kriteria inklusi dan eksklusi hingga didapat 14 literatur.

\section{HASIL PENELITIAN}

Tabel 1 menunjukkan hasil utama literatur yang digunakan dalam penelitian. Jumlah sampel yang digunakan dalam 14 literatur tersebut sebanyak 260 sampel yang terdiri dari 163 ekor tikus jantan (Rattus norvegicus), 89 ekor mencit jantan (Mus musculus), 8 ekor monyet ekor panjang (Macaca fascicularis), dan terdapat 1 literatur yang tidak menyebutkan jumlah sampel yang digunakan. Jumlah sampel yang digunakan dalam 14 literatur tersebut bervariasi dari 8 hingga 35 sampel.

Bila dilihat dari analisis data yang digunakan, uji ANOVA ( $\mathrm{n}=7$ ), uji posthoc Least Significant Different (LSD) $(\mathrm{n}=$ $5)$, uji post-hoc Duncan $(\mathrm{n}=1)$, uji $\mathrm{T}$ independen $(n=2)$, uji $T(n=1)$, uji Cochran $(n=1)$, uji Friedman $(n=1)$ dan uji Kruskal-Wallis $(\mathrm{n}=1)$. Berdasarkan literatur yang menyertakan konsentrasi, motilitas dan morfologi spermatozoa sebagai parameter kualitas spermatozoa, terdapat 10 literatur yang menyertakan konsentrasi, motilitas, dan morfologi spermatozoa sebagai parameter studi dalam penilaian kualitas spermatozoa. Sedangkan 4 lainnya yakni penelitian Reryd Arindany (2015) hanya menyertakan 2 parameter studi (konsentrasi dan motilitas spermatozoa), penelitian Hendri Busman (2018) dan Euis Julaeha (2015) hanya menyertakan 2 parameter studi (motilitas dan morfologi spermatozoa), dan penelitian Novi Prasetyaningrum (2015) hanya menyertakan 1 parameter (motilitas spermatozoa).

Dari 14 literatur yang terpilih terdapat 11 literatur yang menyertakan konsentrasi spermatozoa sebagai parameter studi. Namun hanya 8 literatur yang data hasil penelitiannya memberikan respon bermakna berupa penurunan konsentrasi dari spermatozoa. Tiga literatur yang data hasil penelitiannya tidak menunjukkan respon bermakna tersebut yakni penelitian yang dilakukan oleh Kyrie E. Wenur (2016): Tidak terdapat perbedaan yang signifikan pada konsentrasi spermatozoa antara kelompok kontrol $\left(46,66 \times 10^{6}\right)$ dan kelompok perlakuan $2\left(41,33 \times 10^{6}\right)(\mathrm{p}>$ 0,05), Rionaldy Walansendow (2016): Konsentrasi spermatozoa tidak menunjukkan perubahan $(\mathrm{p}>0,05)$ dan Tuti Nuraini (2012): Terlihat adanya penurunan konsentrasi spermatozoa setelah intervensi meskipun penurunannya tidak bermakna secara statistik $(p=0,607)$. Demikian juga jika dibandingkan dengan kontrol, tidak terdapat perbedaan yang bermakna pada konsentrasi spermatozoa $(p=0,557)$.

Dari 14 literatur yang terpilih, semua literatur tersebut menyertakan motilitas spermatozoa sebagai parameter studi. Namun dari data hasil penelitian literatur tersebut, hanya 13 literatur yang memberikan respon bermakna berupa penurunan motilitas dari spermatozoa. Satu literatur yang tidak memberikan respon bermakna tersebut penelitian yang dilakukan oleh Rionaldy Walansendow (2016) dengan hasil penelitian motilitas 
spermatozoa tidak menunjukkan perubahan $(\mathrm{p}>0,05)$.

Dari 14 literatur yang terpilih terdapat 12 literatur yang menyertakan morfologi spermatozoa sebagai parameter studi dan semua data hasil penelitian dari literatur tersebut memberikan respon bermakna berupa penurunan morfologi normal dari spermatozoa.

Tabel 1. Hasil utama literatur yang digunakan dalam penelitian

\begin{tabular}{|c|c|c|c|c|c|}
\hline No. & Peneliti & $\begin{array}{c}\text { Tempat } \\
\text { penelitian }\end{array}$ & Sampel & $\begin{array}{c}\text { Analisis } \\
\text { Data }\end{array}$ & Hasil Penelitian \\
\hline 1. & $\begin{array}{l}\text { Nita } \\
19)^{8}\end{array}$ & $\begin{array}{l}\text { Sumatera } \\
\text { Selatan, } \\
\text { Indonesia }\end{array}$ & $\begin{array}{c}32 \text { ekor } \\
\text { tikus } \\
\text { jantan } \\
\text { dan } \\
\text { sehat } \\
\text { (Rattus } \\
\text { norvegic } \\
\text { us) } \\
\text { strain } \\
\text { Wistar. }\end{array}$ & $\begin{array}{c}\text { Uji } \\
\text { ANOVA, } \\
\text { uji post } \\
\text { hoc } \\
\text { Duncan. }\end{array}$ & $\begin{array}{l}\text { Konsentrasi: Kelompok } 2,3 \text { dan } 4 \text { bermakna } \\
\text { secara statistik dalam menurunkan kuantitas } \\
\text { spermatozoa dibandingkan dengan kelompok } \\
\text { control (p <0,05). } \\
\text { Motilitas: Kelompok 2, } 3 \text { dan } 4 \text { secara statistik } \\
\text { signifikan dalam menurunkan motilitas sperma } \\
\text { dibandingkan dengan kelompok kontrol (p < } \\
\text { 0,05). } \\
\text { Morfologi: Kelompok 2, } 3 \text { dan } 4 \text { secara } \\
\text { statistik signifikan dalam menurunkan } \\
\text { morfologi normal spermatozoa dibandingkan } \\
\text { dengan kelompok kontrol. }\end{array}$ \\
\hline 2. & $\begin{array}{c}\text { Hendri } \\
\text { Busman } \\
(2018)^{9}\end{array}$ & $\begin{array}{c}\text { Bandar } \\
\text { Lampung } \\
\text { Indonesia }\end{array}$ & $\begin{array}{l}20 \text { ekor } \\
\text { mencit } \\
\text { Swiss } \\
\text { albino } \\
\text { jantan. }\end{array}$ & $\begin{array}{l}\text { Uji } \\
\text { ANOVA } \\
\text { dan uji } \\
\text { Fisher's } \\
\text { LSD } \\
\text { (Least } \\
\text { Significan } \\
\quad t \\
\text { Different) }\end{array}$ & $\begin{array}{l}\text { Konsentrasi: - } \\
\text { Motilitas: Terlihat jelas bahwa dibandingkan } \\
\text { dengan kelompok kontrol, tikus yang diberikan } \\
\text { ekstrak pada dosis } 4 \mathrm{mg} / \mathrm{g} \text { atau } 8 \mathrm{mg} / \mathrm{g} \text { secara } \\
\text { signifikan menurunkan motilitas spermatozoa } \\
\text { sesuai dengan peningkatan dosis }(\mathrm{p}<0,05) \text {. } \\
\text { Morfologi: Morfologi normal spermatozoa } \\
\text { menurun setelah pemberian ekstrak biji pepaya } \\
\text { dosis } 4 \text { dan } 8 \mathrm{mg}(\mathrm{p}<0,05) \text {. }\end{array}$ \\
\hline 3 & $\begin{array}{c}\text { Kyrie E. } \\
\text { Wenur } \\
(2016)^{10}\end{array}$ & $\begin{array}{l}\text { Sulawesi } \\
\text { Utara, } \\
\text { Indonesia }\end{array}$ & $\begin{array}{l}9 \text { ekor } \\
\text { tikus } \\
\text { wistar } \\
\text { jantan } \\
\text { (Rattus } \\
\text { norve- } \\
\text { gicus). }\end{array}$ & $\begin{array}{c}\text { Uji T } \\
\text { independe } \\
n\end{array}$ & $\begin{array}{l}\text { Konsentrasi: Tidak terdapat perbedaan yang } \\
\text { signifikan pada konsentrasi spermatozoa antara } \\
\text { kelompok kontrol dan kelompok perlakuan } 2 \\
(\mathrm{p}>0,05) \text {. } \\
\text { Motilitas: Terdapat perbedaan signifikan pada } \\
\text { motilitas spermatozoa antara kelompok kontrol } \\
\text { dan kelompok perlakuan } 2 \text { ( } \mathrm{p}<0,05) \text {. } \\
\text { Morfologi: Terdapat perbedaan signifikan } \\
\text { pada morfologi spermatozoa antara kelompok } \\
\text { kontrol dan kelompok perlakuan } 2(\mathrm{p}<0,05) \text {. }\end{array}$ \\
\hline 4. & $\begin{array}{c}\text { Rionaldy } \\
\text { Walansen } \\
\text { dow } \\
(2016)^{11}\end{array}$ & $\begin{array}{c}\text { Sulawesi } \\
\text { Utara, } \\
\text { Indonesia }\end{array}$ & $\begin{array}{l}9 \text { ekor } \\
\text { tikus } \\
\text { wistar } \\
\text { jantan } \\
\text { (Rattus } \\
\text { norve- } \\
\text { gicus). }\end{array}$ & $\begin{array}{c}\text { Uji T } \\
\text { independen }\end{array}$ & $\begin{array}{l}\text { Konsentrasi: Konsentrasi spermatozoa tidak } \\
\text { menunjukkan perubahan }(\mathrm{p}>0,05) \text {. } \\
\text { Motilitas: Motilitas spermatozoa tidak } \\
\text { menunjukkan perubahan }(\mathrm{p}>0,05) \text {. } \\
\text { Morfologi: Morfologi normal mengalami } \\
\text { penurunan yang signifikan }(\mathrm{p}<0,005) \text { secara } \\
\text { statistik terlihat adanya penurunan morfologi } \\
\text { spermatozoa yang normal }(\mathrm{p}=0,000) \text {. }\end{array}$ \\
\hline
\end{tabular}




\begin{tabular}{rrrrl}
\hline 5. Waqiatul & Surabaya, & 21 ekor & Uji one- & Konsentrasi: Campuran ekstrak biji pepaya \\
Hasanah & Indonesia & mencit & way & dan ekstrak daun mimba dengan dosis 100:100 \\
$(2016)^{12}$ & & jantan & ANOVA & mg/kg bb menyebabkan penurunan konsentrasi \\
& & $($ Mus & dan uji & spermatozoa mencit. \\
& & musculus $).$ & LSD & Motilitas: Campuran ekstrak biji pepaya dan \\
& (Least & ekstrak daun mimba dengan dosis 100:100 \\
& Significant & mg/kg bb menyebabkan penurunan motilitas \\
& Different $)$ & spermatozoa mencit.
\end{tabular}

Morfologi: Campuran ekstrak biji pepaya dan ekstrak daun mimba dengan dosis 100:100 $\mathrm{mg} / \mathrm{kg}$ bb menyebabkan penurunan morfologi normal spermatozoa mencit.

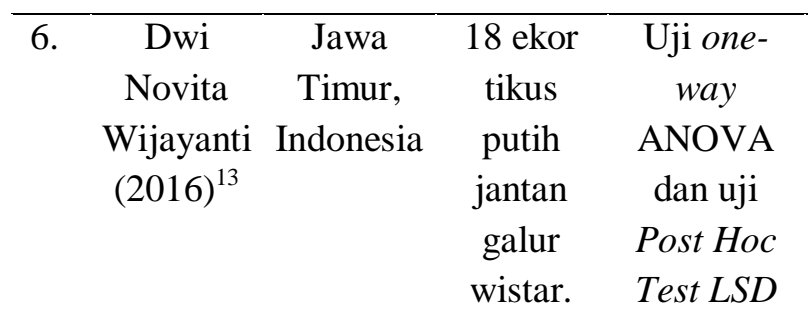

Konsentrasi: Kelompok perlakuan ekstrak biji pepaya muda memiliki jumlah spermatozoa lebih rendah dibandingkan kelompok ekstrak biji pepaya tua. Ekstrak biji pepaya muda juga memiliki perbedaan yang signifikan terhadap kelompok kontrol negatif dan ekstrak biji pepaya tua dengan $\mathrm{p}=0,000 \quad(\mathrm{p}<$ $0,05)$.

Motilitas: Kelompok ekstrak metanol biji pepaya muda mempunyai motilitas spermatozoa yang lebih rendah dibandingkan dengan ekstrak metanol biji pepaya tua. Ekstrak biji pepaya muda juga memiliki perbedaan yang signifikan terhadap kelompok kontrol negatif dan ekstrak biji pepaya tua dengan $\mathrm{p}=0,000 \quad(\mathrm{p}<0,05)$.

Morfologi: Terjadi penurunan jumlah (\%) spermatozoa normal setelah pemberian ekstrak metanol biji pepaya tua dan muda. Kelompok perlakuan ekstrak metanol biji pepaya muda memiliki jumlah (\%) spermatozoa normal lebih rendah dibandingkan kelompok ekstrak biji pepaya tua. Ekstrak biji pepaya muda memiliki perbedaan yang signifikan terhadap kelompok kontrol negatif dan ekstrak biji pepaya tua dengan $\mathrm{p}=0,000(\mathrm{p}<0,05)$.

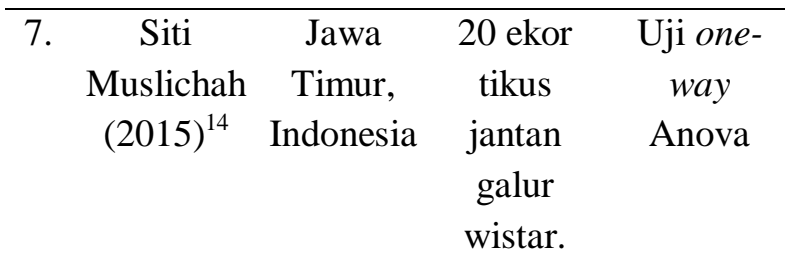

Konsentrasi: Hasil uji statistik menggunakan One-Way Anova terhadap perubahan jumlah spermatozoa tikus jantan menunjukkan perbedaan yang signifikan $(\mathrm{p}<0,05)$ setelah pemberian fraksi $\mathrm{n}$-heksana, kloroform dan metanol biji pepaya dibanding kelompok kontrol.

Motilitas: Motilitas spermatozoa tikus jantan menunjukkan perbedaan yang signifikan $(\mathrm{p}<$ $0,05)$ setelah pemberian fraksi n-heksana, 


\begin{tabular}{|c|c|c|c|c|c|}
\hline & & & & & $\begin{array}{l}\text { kloroform dan methanol biji pepaya dibanding } \\
\text { kelompok kontrol. } \\
\text { Morfologi: Terdapat perbedaan yang } \\
\text { signifikan terhadap abnormalitas spermatozoa } \\
(\mathrm{p}<0,05) \text {. Abnormalitas meningkat secara } \\
\text { bermakna setelah perlakuan. }\end{array}$ \\
\hline 8. & $\begin{array}{c}\text { Euis } \\
\text { Julaeha, } \\
(2015)^{15}\end{array}$ & $\begin{array}{c}\text { Jawa } \\
\text { Barat, } \\
\text { Indonesia }\end{array}$ & $\begin{array}{l}\text { Tikus } \\
\text { jantan } \\
\text { dewasa } \\
\text { (R.Nor- } \\
\text { vegicus) }\end{array}$ & - & $\begin{array}{l}\text { Konsentrasi: - } \\
\text { Motilitas: Pada konsentrasi } 12,5 \mathrm{ng} / \mu \mathrm{L} \text {, } \\
\text { senyawa tersebut dapat menurunkan motilitas } \\
\text { sebanyak } 18 \% \text {. } \\
\text { Morfologi: Pada konsentrasi } 12,5 \mathrm{ng} / \mu \mathrm{L} \text {, } \\
\text { senyawa tersebut terjadi peningkatan } \\
\text { abnormalitas sebanyak } 294 \% \text {. }\end{array}$ \\
\hline 9. & $\begin{array}{c}\text { Soni } \\
\text { Kumari } \\
(2015)^{16}\end{array}$ & $\begin{array}{l}\text { Bihar, } \\
\text { India }\end{array}$ & $\begin{array}{l}24 \text { ekor } \\
\text { mencit } \\
\text { dewasa } \\
\text { Swiss } \\
\text { albino } \\
\text { (Mus } \\
\text { musculus })\end{array}$ & Uji T & $\begin{array}{l}\text { Konsentrasi: Jumlah sperma mencit menurun } \\
\text { secara signifikan setelah pemberian ekstrak biji } \\
\text { pepaya kemudian dibandingkan dengan } \\
\text { kelompok kontrol } \quad(\mathrm{P}<0,001) \text { berturut- } \\
\text { turut selama } 10,20 \text { sampai } 30 \text { hari. } \\
\text { Motilitas: Motilitas sperma menurun secara } \\
\text { signifikan }(\mathrm{P}<0,001) \text { pada Carica pepaya } \\
\text { mencit perlakuan benih dibandingkan } \\
\text { kelompok kontrol mencit. } \\
\text { Morfologi: Kelainan spermatozoa meningkat } \\
\text { secara signifikan } \quad(\mathrm{P}<0,001) \text { pada } \\
\text { kelompok perlakuan dibandingkan kelompok } \\
\text { kontrol. }\end{array}$ \\
\hline 10 & $\begin{array}{c}\text { Reryd } \\
\text { Arindany } \\
\text { Wiryawan } \\
(2015)^{17}\end{array}$ & $\begin{array}{l}\text { Surabaya, } \\
\text { Indonesia }\end{array}$ & $\begin{array}{l}28 \text { ekor } \\
\text { mencit } \\
\text { jantan } \\
\text { (Mus } \\
\text { musculus) } \\
\text {. }\end{array}$ & $\begin{array}{l}\text { Uji one- } \\
\text { way } \\
\text { ANOVA } \\
\text { dan uji } \\
\text { LSD (Least } \\
\text { Significant } \\
\text { Different) }\end{array}$ & $\begin{array}{l}\text { Konsentrasi: Dalam penelitian ini terdapat } \\
\text { perbedaan nilai rata-rata tiap kelompok. Uji } \\
\text { normalitas data konsentrasi sperma diperoleh } \mathrm{p} \\
>0,005 \text { dapat disimpulkan bahwa data } \\
\text { berdistribusi normal kecuali pada perlakuan } \\
\text { ketiga konsentrasi dimana } p<0,05 \text {. } \\
\text { Motilitas: Uji normalitas data konsentrasi } \\
\text { sperma diperoleh } p>0,005 \text { dapat disimpulkan } \\
\text { bahwa data berdistribusi normal kecuali pada } \\
\text { perlakuan ketiga konsentrasi dimana } p<0,05 \text {. } \\
\text { Terdapat penurunan jumlah sel sperma yang } \\
\text { bergerak secara progresif meningkat sesuai } \\
\text { dosis. } \\
\text { Morfologi: - }\end{array}$ \\
\hline 11 & $\begin{array}{c}\text { Novi } \\
\text { Prasetya } \\
\text { ningrum } \\
(2015)^{18}\end{array}$ & $\begin{array}{c}\text { Jawa } \\
\text { Timur, } \\
\text { Indonesia }\end{array}$ & $\begin{array}{l}20 \text { ekor } \\
\text { tikus } \\
\text { jantan. }\end{array}$ & $\begin{array}{l}\text { Uji one- } \\
\text { way } \\
\text { ANOVA } \\
\text { dan uji } \\
\text { LSD (Least } \\
\text { Significant } \\
\text { Different) }\end{array}$ & $\begin{array}{l}\text { Konsentrasi: - } \\
\text { Motilitas: Rata-rata persen motilitas } \\
\text { spermatozoa pada masing-masing perlakuan } \\
\text { menunjukkan adanya penurunan dibandingkan } \\
\text { kelompok kontrol negatif yang hanya diberi } \\
\text { CMC-Na 1\%. } \\
\text { Morfologi: - }\end{array}$ \\
\hline
\end{tabular}




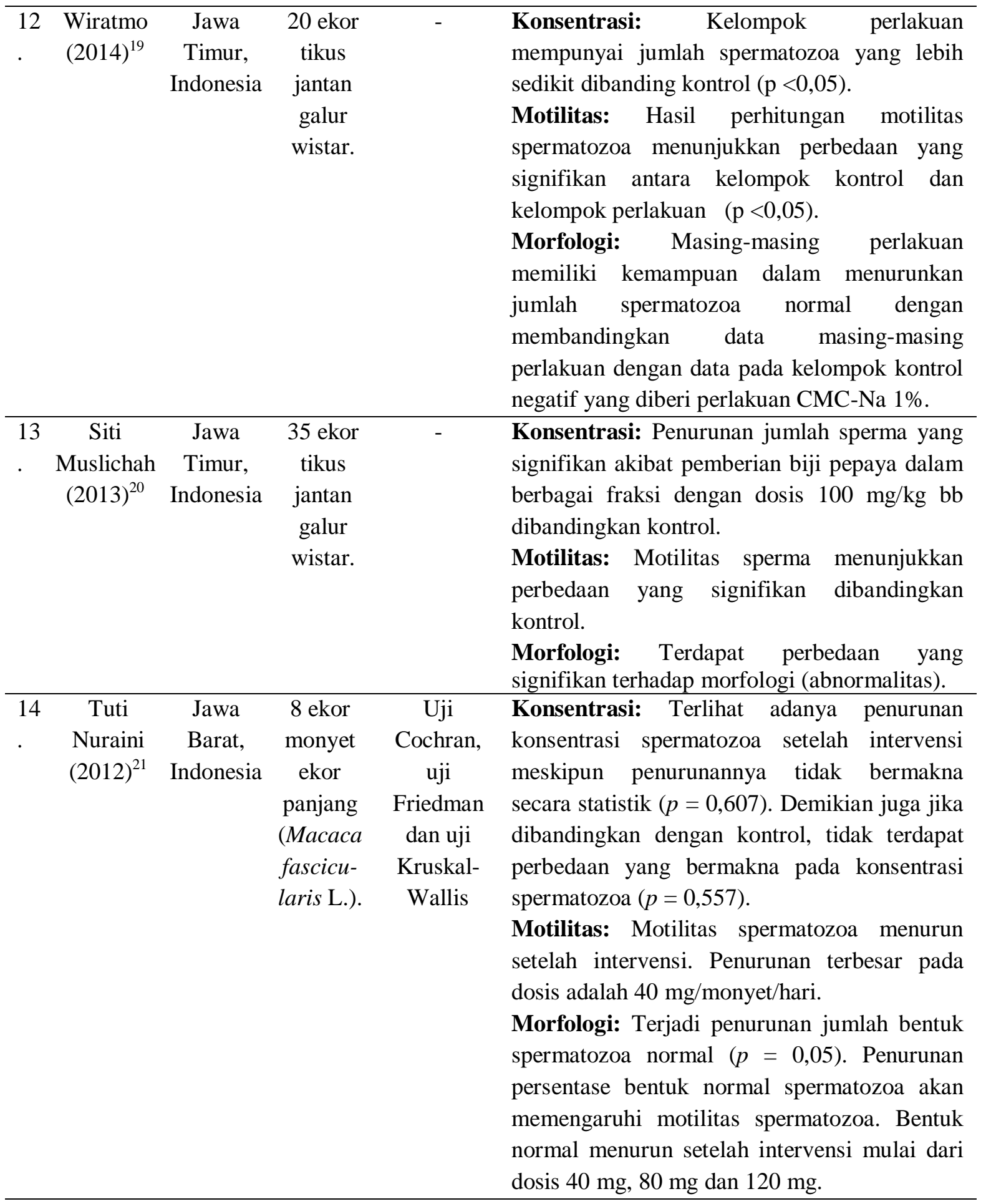

\section{BAHASAN}

Pada analisis data hasil penelitian pada literatur-literatur yang direview menunjukkan bahwa ekstrak biji pepaya (Carica papaya L.) berpengaruh terhadap kualitas spermatozoa seperti penurunan konsentrasi, penurunan motilitas dan penurunan morfologi normal spermatozoa.
Dari 14 literatur yang membahas tentang pengaruh ekstrak biji pepaya (Carica papaya L.) terhadap kualitas spermatozoa, $11 \quad$ diantaranya memperlihatkan adanya respon bermakna berupa penurunan terhadap konsentrasi spermatozoa. Hal ini disebabkan oleh kandungan senyawa alkaloid, tanin, saponin dan triterpenoid pada biji 
pepaya. ${ }^{12,19}$ Pada penelitian Dwi Novita Wijayanti (2016) menjelaskan bahwa penurunan jumlah spermatozoa (juta/ml) disebabkan oleh senyawa alkaloid dalam biji pepaya dapat menyebabkan degenerasi sel sperma serta menurunkan jumlah sel sperma. Senyawa alkaloid ini juga memberikan efek sitotoksik yang dapat mengganggu sel germinal dan sel spermatogenik. Menurunnya jumlah sel spermatogenik juga disebabkan oleh menurunnya kadar hormon testosteron akibat dari senyawa kimia dalam biji pepaya yang bersifat sitotoksik dan menyebabkan metabolisme sel spermatogenik terganggu seperti alkaloid, triterpenoid dan steroid. ${ }^{13}$

Pada penelitian Reryd Arindany Wiryawan (2015) menjelaskan tentang senyawa alkaloid yang terdapat dalam biji pepaya memiliki reaksi estrogenik yang berdampak pada penurunan hormon testosteron. Efek estrogenik akan menekan hipotalamus dan hipofisis anterior yang menyebabkan hormon GnRH dan gonadotropin (FSH dan $\mathrm{LH}$ ) terhambat dan tidak merangsang sel Leydig untuk memproduksi testosteron untuk berperan dalam spermatogenesis sehingga konsentrasi spermatozoa menurun. ${ }^{17}$

Pada penelitian Sri Nita (2019) menjelaskan bahwa triterpenoid dan steroid yang terkandung dalam biji pepaya memengaruhi kadar testosteron dengan menghambat mekanisme umpan balik di hipofisis-hipotalamus untuk mengurangi produksi LH dan FSH. FSH merangsang proses spermatogenesis dan $\mathrm{LH}$ merangsang pertumbuhan dan metabolism sel Leydig untuk menghasilkan hormon testosteron. Jumlah sperma dan kadar testosteron dipertahankan konstan oleh mekanisme umpan balik. Jika mekanisme umpan balik terganggu maka kadar FSH dan LH dalam sirkulasi darah dapat menurun. Akibatnya proses spermatogenesis terhenti dan jumlah spermatozoa yang dihasilkan pada tubulus seminiferus menurun. ${ }^{8}$

Dari 14 literatur yang membahas tentang pengaruh ekstrak biji pepaya
(Carica papaya L.) terhadap kualitas spermatozoa, 13 literatur yang memberikan respon bermakna berupa penurunan motilitas dari spermatozoa. Motilitas spermatozoa berasal dari kemampuan spermatozoa mendorong diri maju ke depan akibat adanya substansi kontraktil pada bagian tubuh spermatozoa kemudian diteruskan ke seluruh bagian ekor spermatozoa. Pada penelitian Novi Prasetyaningrum (2015) yang khusus melihat pengaruh ekstrak metanol, fraksi nheksana dan fraksi metanol biji pepaya terhadap motilitas spermatozoa, hasil pengamatan spermatozoa ditemukan sperma yang termasuk sperma asthenozoospermia (motilitas sperma kurang dari 40\%). Asthenozoospermia terbanyak pada sperma tikus pada perlakuan fraksi metanol biji pepaya. Ratarata persen motilitas spermatozoa pada masing-masing perlakuan menunjukkan penurunan dibandingkan kelompok kontrol. Diantara ketiga perlakuan, fraksi metanol yang memiliki jumlah motilitas spermatozoa yang paling rendah yaitu 10,6 $\pm 4,16 \%$ sedangkan pada ekstrak metanol: 29,8\% dan fraksi n-heksana 38\%. Pada penelitian ini dikatakan bahwa dugaan penurunan motilitas spermatozoa tidak disebabkan oleh tahap pematangan di epididimis, melainkan sudah terjadi ketika masih di dalam testis. Hal ini dilihat pengaruh ekstrak biji pepaya terhadap struktur histologis epididimis, yaitu terjadinya penyempitan tubulus, namun tidak memengaruhi fungsi sekresi dan absorbsi dari sel-sel epididimis. ${ }^{22}$ Hal yang paling menentukan motilitas spermatozoa adalah tahap spermatogenesis. Bila pada saat perubahan spermatid menjadi spermatozoa berjalan tidak normal, maka pembentukan akrosom dan mitokondria akan memengaruhi keberhasilan motilitas dalam epididimis. ${ }^{18}$ Gerakan ekor yang cepat dan kuat mampu mendorong spermatozoa masuk ke dalam membran serviks dan akhirnya menembus sel telur. Spermatozoa dapat menjadi motil karena adanya energi yang terdapat pada bagian leher kemudian disalurkan kebagian ekor. 
Sehingga kunci untuk kemampuan bergerak dari spermatozoa adalah adanya produksi energi oleh mitokondria dibagian leher spermatozoa. Diduga bahwa ekstrak biji pepaya menyebabkan abnormalitas organel sel pada bagian leher spermatozoa yaitu berupa vakuolisasi pada mitokondria dan abnormalitas struktur berupa leher bengkok. Hal inilah yang menjadi penyebab tidak maksimalnya fungsi mitokondria dalam menghasilkan energi dan akhirnya berpengaruh terhadap motilitas spermatozoa. Ekstrak biji pepaya secara langsung memengaruhi mekanisme pembentukan spermatozoa. Hal ini dapat dilihat dengan adanya korelasi antara jumlah dan motilitas spermatozoa pada kelompok perlakuan lebih sedikit bila dibandingkan dengan kelompok kontrol. Hal ini menunjukkan bahwa biji pepaya memengaruhi proses spermatogenesis pada tahap perubahan spermatid menjadi spermatozoa. Bila spermatozoa yang dihasilkan mengalami abnormalitas dalam pembentukannya, hal tersebut akan berpengaruh juga pada saat proses pematangan di epididimis. ${ }^{14}$

Pada penelitian Hendri Busman (2018) dan Waqiatul Hasanah (2016) menjelaskan bahwa terdapat beberapa senyawa aktif yang terkandung dalam biji pepaya seperti alkaloid, tanin, saponin dan triterpenoid dapat mengganggu proses transportasi sperma yang menggumpalkan sperma akhirnya menurunkan motilitasnya. Senyawa aktif lain dalam biji pepaya seperti glukosinolat juga perlu diperhatikan efeknya. ${ }^{12,23}$ Berbeda dengan penjelasan sebelumnya, pada penelitian Siti Muslichah (2015) dan Tuti Nuraini (2012) dijelaskan bahwa kemungkinan mekanisme ekstrak biji pepaya dalam menginduksi inhibisi motilitas sperma disebabkan oleh kandungan glukosinolat yang ada pada ekstrak biji memengaruhi pembentukan plasma semen. Glukosinolat diduga menghambat pematangan sperma dan memengaruhi pembentukan semen plasma sebagai media transportasi sperma. Kemungkinan besar ekstrak biji pepaya memengaruhi proses pengangkutan sperma dengan cara menggumpalkan semen sehingga motilitas dan morfologi sperma menurun. Mekanisme aglutinasi di tingkat epididimis terjadi dengan adanya gangguan komposisi cairan dari epididimis dan mempengaruhi enzim yang diproduksi oleh sperma. Ekstrak biji pepaya juga diketahui mengandung enzim penghancur polipeptida yang biasa disebut dengan papain. Papain merupakan enzim protease yang dapat menghambat motilitas sperma dalam plasma semen. ${ }^{14,21}$

Penjelasan lain pada penelitian Dwi Novita Wijayanti (2016) dan Soni Kumari (2016), dijelaskan bahwa efek sitotoksik dari kandungan senyawa dalam biji pepaya yaitu alkaloid, steroid, triterpenoid dapat mengganggu metabolisme sel germinal dan sel spermatogenik. Alkaloid diduga dapat mengganggu aktivitas enzim ATP-ase pada membran sel spermatozoa dibagian tengah ekor. Enzim ATP-ase ini berfungsi dalam mempertahankan homeostasis internal untuk ion natrium dan kalium. Terganggunya aktivitas enzim ATPase, maka homeostasis ion natrium dan kalium akan mengalami gangguan sehingga konsentrasi $\mathrm{Na}+$ intrasel meningkat, gradien $\mathrm{Na}+$ melintasi membran sel akan menurun sehingga pengeluaran $\mathrm{Ca} 2+$ juga akan mengalami penurunan. Berkurangnya ion $\mathrm{Ca} 2+$ akan mengakibatkan membran kehilangan kemampuannya dalam mengangkut bahan-bahan terlarut ke dalam. Dengan terganggunya permeabilitas membran sperma akan menyebabkan transpor nutrien yang diperlukan oleh spermatozoa untuk pergerakannya terganggu. ${ }^{13,16}$

Dari 14 literatur yang membahas tentang pengaruh ekstrak biji pepaya (Carica papaya L.) terhadap kualitas spermatozoa, terdapat 12 literatur yang menyertakan morfologi spermatozoa sebagai parameter studi dan semua data hasil penelitian dari literatur tersebut memberikan respon bermakna berupa penurunan morfologi normal dari spermatozoa. Penurunan morfologi normal dari spermatozoa ini disebabkan oleh kemampuan papain yang terkandung dalam 
ekstrak untuk memutus ikatan kimiawi dalam molekul protein-bahan mentah sintesis hormon reproduksi, sehingga protein terurai menjadi peptide dan akibatnya sintesis hormon reproduksi akan menurun. Papain dapat merusak organel Sertoli dan sel spermatogenik sehingga komponen sel pada tubulus seminiferus mengalami degenerasi. Senyawa papain yang terkandung dalam biji pepaya diduga dapat menghambat androgen, sehingga terjadi gangguan pada spermatogenesis yang menyebabkan kelainan sperma. $^{23}$ Pada penelitian Kyrie E. Wenur (2016) dijelaskan bahwa peningkatan morfologi spermatozoa abnormal terjadi akibat ekstrak biji pepaya menyebabkan terjadinya abnormalitas organela sel pada bagian leher spermatozoa, yaitu vakuolisasi pada mitokondria. ${ }^{10}$ Abnormalitas spermatozoa yang diamati oleh Rionaldy Walansendow (2016) dalam penelitiannya paling banyak menemukan bentuk abnormalitas sekunder, yaitu ekor yang terlilit dan patahan pada ekor. Sedangkan abnormalitas primer yang ia temukan berupa kelainan leher, seperti tanpa kepala dan tanpa ekor. Ditemukannya abnormalitas primer ini diduga karena adanya gangguan spermatogenesis pada fase spermatogenesis, tepatnya saat pembentukan spermatozoa dari spermatid, sedangkan abnormalitas sekunder diduga karena terjadi gangguan pada saat maturasi spermatozoa di epididimis. Kandungan enzim papain yang terdapat di dalam ekstrak biji pepaya juga dapat menurunkan total lipid pada jaringan testis dan epididimis. Ekstrak biji pepaya menurunkan aktivitas enzim lipase lipoprotein dan menghambat absorpsi nutrisi dari sistem gastrointestinal, sedangkan energi yang dihasilkan dari nutrisi tersebut diperlukan untuk proses spermatogenesis di testis dan maturasi spermatozoa di epididimis. ${ }^{11}$

\section{SIMPULAN}

Ekstrak biji pepaya (Carica papaya L.) dapat memengaruhi kualitas spermatozoa yaitu ekstrak biji pepaya (Carica papaya
L.) dapat menurunkan konsentrasi spermatozoa. Ekstrak biji pepaya (Carica papaya L.) dapat menurunkan motilitas spermatozoa. Ekstrak biji pepaya (Carica papaya $L$.) dapat menurunkan morfologi spermatozoa.

\section{Konflik Kepentingan}

Penulis menyatakan tidak terdapat konflik kepentingan dalam studi ini.

\section{DAFTAR PUSTAKA}

1. Agustinus, I'tishom R, Pramesti MPBD. Biologi reproduksi pria. Abadi Z, (ed). Surabaya: Airlangga University Press; PIPS UNAIR, 2018.

2. WHO. WHO Laboratory Manual for the Examination and Processing of Human Semen. 5th ed. Switzererland. WHO. 2010;

3. Akmal M. Androgen Dihydrotestosterone dan Perannya pada Sistem Reproduksi Pria. Veterina Med. 2017;10(1):119-30.

4. Cao XW, Lin K, Li CY, Yuan CW. [A review of WHO Laboratory Manual for the Examination and Processing of Human Semen (5th edition)]. Zhonghua Nan Ke Xue. 2011;17(12):1059-63.

5. Finnegan K. Urinalysis and Body Fluids, 6th Edition. Vol. 46, Laboratory Medicine. 2015. 38-38 p.

6. Sekeli R, Hamid MH, Razak RA, Wee CY, Ong-Abdullah J. Malaysian carica papaya 1. var. eksotika: current research strategies fronting challenges. Front Plant Sci. 2018;9(September):1-9.

7. Ming R, Moore PH. Genetics and genomics of papaya. Genet Genomics Papaya. 2014;(December 2019):1-438.

8. Nita S, Setiawan A, Inggarsih R, Tantri U, Hardiana M. Papaya (Carica Papaya L.) Seed Extract as Male Contraception via Decreasing The Quality of Rat's (Rattus Norvegicus) Sperm. Bioscientia Medicine: Journal of Biomedicine 
and Translational Research. 2020;4(1):19-28.

9. Busman H, Nurcahyani N, Sutyarso, Dewi ERS, Kanedi M. Sperms Quality of Mice Decreased By Seed Extract of Papaya (Carica Papaya L.). Eur J Biomed Pharmceutical Sci. 2018;5(8): 958.

10. Wenur KE, Satiawati L, Tendean L. Perbandingan kualitas spermatozoa tikus wistar (Rattus norvegicus) yang diberi ekstrak buah pare (Momordica charantia $L)$ dengan ekstrak biji pepaya (Carica papaya L). e-Biomedik. 2016;4(2):1-4.

11. Walansendow R, Rumbajan JM, Tendean L. Pengaruh Pemberian Ekstrak Biji Pepaya (Carica Papaya L.) Terhadap Kualitas Spermatozoa Tikus Wistar (Rattus Norvegicus). e-Biomedik. 2016; 4(1).

12. Ervina E, Sukarjati S. Pengaruh Pemberian Ekstrak Biji Pepaya (Carica papaya L.), Ekstrak Daun Mimba (Azadiracta indica A. Juss) serta Campuran Ekstrak Biji Pepaya dan Ekstrak Daun Mimba Terhadap Gambaran Histologi Ginjal dan Hati Mencit Jantan (Mus musculus L). Wahana. 2017;68(1):61-9.

13. Wijayanti DN, Muslichah S, Puspitasari E. Pengaruh Ekstrak Metanol Biji Pepaya Tua dan Ekstrak Metanol Biji Pepaya Muda (Carica papaya L.) terhadap Kualitas dan Kuantitas Spermatozoa Tikus Putih Jantan (Rattus norvegicus) (Effect of Methanolic Extract of Ripe and Raw Papaya Seeds (Carica papaya). Pustaka Kesehat. 2016;4(3):495-500.

14. Muslichah S, Wiratmo. Efek Antifertilitas Fraksi N-Heksana, Fraksi Kloroform, dan Fraksi Metanol Biji Pepaya (Carica papaya L.) Terhadap Tikus Jantan
Galur Wistar. Jurnal Farmasi Sains dan Terapan 2015;2(2):10-4.

15. Julaeha E, Permatasari Y, Mayanti T, Diantini A. Antifertility Compound from the Seeds of Carica papaya. Procedia Chem. 2015;17:66-9.

16. Singh SKRKVN. Contraceptive Effects of Aqueous Extract Of Carica Papaya (Linn.) Seed on Seminal Profile of Swiss Albinomice. Int J Sci Res. 2015;6(8):1963-5.

17. Wiryawan RA, I'tishom R, Purwaningsih S. Papaya Seed Extract Lowers Sperm Concentrations, Motility and Viability in Male Mice. Folia Medica Indones. 2015;51(4):2526.

18. Novi Prasetyaningrum, Siti Muslichah MAH. Pengaruh Ekstrak Metanol, Fraksi N-Heksana, dan Fraksi Metanol Biji Pepaya (Carica papaya L.) terhadap Kadar Testosteron dan Bobot Organ Reproduksi Tikus Jantan (Effect of Methanolic Extract, N-Hexanic Fraction, and Methanolic Fraction of Papaya Seed). Pustaka Kesehat. 2015;3:39-43.

19. Wiratmo SM. Pengembangan Formula Jamu Antifertilitas Pria dari Kombinasi Fraksi Aktif Biji Saga (Abrus precatorius) dan Biji Pepaya (Carica papaya). Fak Farm Univ Jember. 2014;1-13.

20. Muslichah S, Wiratmo. Efek Antifertilitas Fraksi N-heksana, Fraksi Kloroform dan Fraksi Metanol Biji Saga (Abrus precatorius L.) dan Biji Pepaya (Carica papaya L.) Terhadap Tikus Jantan Galur Wistar. Jember: Fakultas Farmasi Universitas Jember, 2013.

21. Nuraini T, Kusmana D, Afifah E. Penyuntikan ekstrak biji Carica papaya $L$. varietas cibinong pada Macaca fascicularis $L$. dan kualitas spermatozoa serta kadar 
hormon testosteron. Makara J Heal Res. 2012;16(1):9-16.

22. Lohiya NK, Mishra PK, Pathak N, Manivannan B. Efficacy trial on the purified compounds of the seeds of Carica papaya for male contraception in albino rat Efficacy trial on the purified compounds of the seeds of Carica papaya for male contraception in albino rat. Reprod Toxicol. 2005;(May).

23. Nurcahyani N, Busman H, Rahmawati PD. Antispermatogenic Effect of Seeds Extract of Papaya (Carica papaya L.) in Mice. Pharm Chem J. 2018;5(4):18-22 